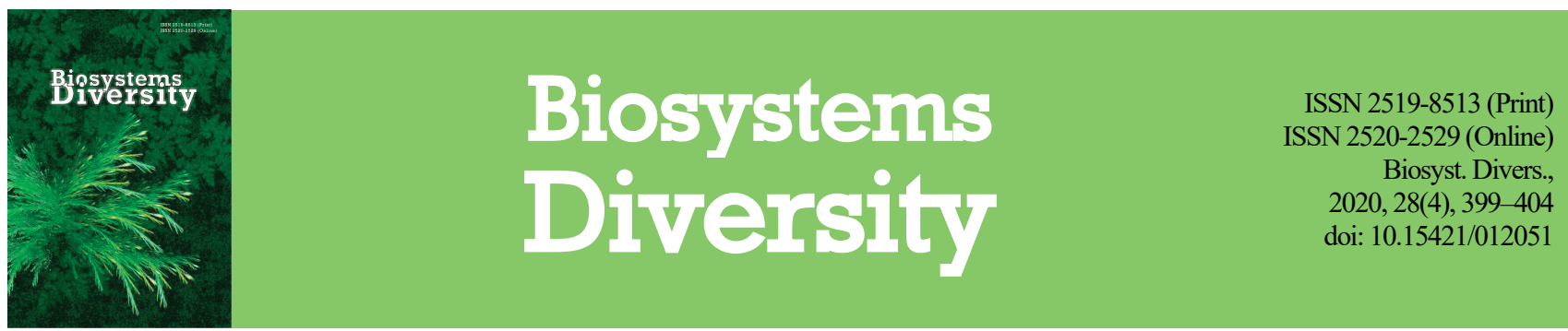

\title{
Diversity of Sambucus nigra pollen within Slovakia in selected morphological characters by SEM study
}

\author{
V. Horčinová Sedláčková*, O. Grygorieva**, I. Gurnenko**, O. Vergun** \\ *Institute of Biodiversity Conservation and Biosafety, Slovak University of Agriculture in Nitra, Nitra, Slovak Republic \\ **M. M. Gryshko National Botanical Garden of Ukraine, National Academy of Sciences, Kyiv, Ukraine
}

Article info

Received 08.10.2020

Received in revised form 14.11.2020

Accepted 18.11.2020

Institute of Biodiversity

Conservation and Biosafety,

Slovak University of Agriculture

in Nitra, Tr. A. Hlinku st., 2,

Nitra 94976, Slovak Republic.

Tel.: +42-137-641-47-87. E-mail:

vladimira.sedlackova@uniag.sk

M. M. Gryshko National Botanical Garden of Ukraine, National

Academy of Sciences,

Timiryazevska st., 1 ,

Kyiv, 01014, Ukraine.

Tel.: +38-067-198-80-82

E-mail:olgrygorieva@gmail.com
Horčinová Sedláčková, V., Grygorieva, O., Gurnenko, I., Vergun, O. (2020). Diversity of Sambucus nigra pollen within Slovakia in selected morphological characters by SEM study. Biosystems Diversity, 28(4), 399-404. doi:10.15421/012051

This study analyzed pollen morphology and characteristics of 20 Sambucus nigra L. genotypes from populations of various ecotypes and geographical localities from the territory of Slovakia. We used principal component analysis to explore variability in pollen grain size (polar and equatorial diameter), shape, aperture type, and exine ornamentation by scanning electron microscopy. The combination of these morphological characteristics and ultrastructure allows us to determine the differences or similarities between the same and various species and genotypes, which may be a useful tool for systematics with significant diagnostic value. The findings confirmed small differences among the genotypes in measured traits with polar and equatorial diameters in the range from 22.30 to $26.64 \mu \mathrm{m}$ and from 12.81 to $14.45 \mu \mathrm{m}$, respectively. Shape index (P/E ratio) depending on elongation or roundness of pollen grains varied from 1.66 to 2.02. Hierarchical cluster analysis (HCA) and principal component analysis (PCA) of morphological data helped to compare evaluated morphometric parameters and identified three closely related groups. It was noted that the diversity of surface sculpturing of pollen grains in combination with their shape and size enables us to use a complex of fine morphologic signs for S. nigra pollen identification. Pollen data combined with other morphological evidence (e.g., floral characters) have more recently become an important indicator of which genotypes may be the best representatives of species.

Keywords: pollen grains; scanning electron microscopy; morphology characteristic; pollen structure.

\section{Introduction}

Carl Nilsson Linnæus first used the term pollen. In the 18th and the early 19th centuries, there was considerable progress in pollen research and the understanding of pollination. The characteristics of pollen, as a useful tool in better understanding of taxonomy and classification of plants, have been studied in terms of the pollen origin (Kozáková \& Pokorný 2007), pollen morphology and anatomy (Grew, 1682; Erdtman, 1945; Halbritter et al., 2018), physiology of pollen grain surface (HeslopHarrison, 1975; Taia et al., 2013), plant sexuality (Camerarius, 1694; Kessler \& Harley, 2004), DNA identification (Doyle, 2005; Žiarovská et al., 2015), flower pollination (Candolle \& Sprengel, 1821; Aluri \& Reddi, 1995; Wilcock \& Neiland, 2002), pollen germination (Rao \& Ong, 1972; Taia et al., 2013), pollen fertilization (Kessler \& Harley, 2004; Dresselhaus et al., 2016), characteristics of the offspring (Kölreuter, 1761-1766; Stuessy \& Funk, 2013; Ulrich et al., 2012, 2013; Miter et al., 2016), description and figuration of fossil pollen grains and spores (Gee, 2001), medicinal properties (Barbosa et al., 2006; Almaraz-Abarca et al., 2007; Basuny et al., 2013; Nikolaieva et al., 2019).

Pollen grains represent the highly reduced male gametophyte - the enclosing sporoderm and the cellular content, consisting of two or three cells, and the pollen tube (Charzyńska \& Lewandowska, 1989). The transfer of male gametic material by insects classified the genus Sambucus as entomophilous (Farré-Armengol et al., 2015). It is associated with pollen production, which involves incomparably lower investments in male flowers, but they generally have higher investments in the production of rewards and signals for attracting pollinators (Candolle \& Sprengel, 1821; Friedman \& Barrett, 2009). Thus, pollen grains adapted to different strategies also have anatomical-morphological differences. These male haploid organisms usually have as variable parameters: the pollen shape and size, the number, type, and position of apertures, and the pollen wall with its extremely diverse structure and sculpture. The characters of these parameters in comparative pollen (and spore) morphology are at least as important as any other morphological character of the diploid generation (Halbritter et al., 2018). Furthermore, pollen morphological studies proved to be indispensable for the understanding of evolutionary processes and systematics. The ability to identify plants from their pollen has enabled botanists and ecologists to reconstruct past assemblages of plants and identify periods of environmental change (e.g., Fægri \& Iversen, 1989; Moore et al., 1991). Morphological characteristics of pollen grains also can be useful characters in studies of plant taxonomy because many pollen traits are influenced by the strong selective forces involved in various reproductive processes, including pollination, dispersal, and germination (Erdtman, 1952; Nowicke \& Skvarla, 1979; Stuessy, 1990; Moore et al., 1991). Thus, the use of pollen morphology as a taxonomic character is challenging, and pollen characteristics must be considered in concert with other characteristics in evolutionary reconstructions.

The genus Sambucus L., with its complex phylogenetic relationships and clades, at first was assigned to the Caprifoliaceae family. In the phylogenetic context it has been occasionally segregated into Sambucaceae, and after cladistic analysis aimed at determining the phylogenetic relationships within Viburnum-Sambucus-Adoxa was classified to the Adoxaceae family by Bremer et al. (2001) classification. Recently, the Nomenclature Committee for Vascular Plants (NCVP) corrected the name for Adoxaceae sensu APG (Applequist, 2013). Comparative pollen revisions of the tribes of the family Caprifoliaceae and their genera have been examined for at least 60 years. The first knowledge was obtained by using an optical light microscope (LM) as evidenced by Erdtman (1952), Straka (1952), Weberling (1966), Stachurska et al. (1970), Kuprianova \& Alyoshina (1972). On the base of the modern scanning electron microscope (SEM) many authors have studied pollen sculpture of the Caprifoliaceae family (Accorsi et al., 1987; Hu \& He, 1988; Tămas et al., 2009; Tank \& Do- 
noghue, 2010; Tsymbalyuk \& Bezusko, 2017). The study aimed to obtain SEM images of the Sambucus nigra pollen grains in the condition of Slovakia, determine the main morphological traits, and describe the structure of pollen grains in a comparison with literature data. The knowledge of pollen morphological characteristics can be an adequate method for identification of genotypes and allow determination of the differences or similarities between the species.

\section{Materials and methods}

Pollen samples and localization. All pollen samples of S. nigra genotypes (SN-01-SN-20) from populations were collected from several parts of Slovakia (Western, South-Western, and Central, Fig. 1). The trees were localized by GPS (altitude of 109-624 m). The whole territory of Slovakia belongs to the temperate climate zone. As the altitude rises, temperature decreases, precipitation increases, soil type change, and the growing season is shorter. The results of meteorological measurements and observations show that the year of sampling (2008) was extremely rich in rain and storm activity throughout the territory, which began to occur in early March. Fresh flowers (not opened) were collected randomly from the different genotypes at the balloon stage (June 2008). Pollen samples released from dry flowers were further dried under laboratory conditions. The dry pollen was used for a microscopic study of morphological characteristics. The samples of pollen grains were applied to double-tape, fastened to metal object tables with a $10 \mathrm{~mm}$ diameter.

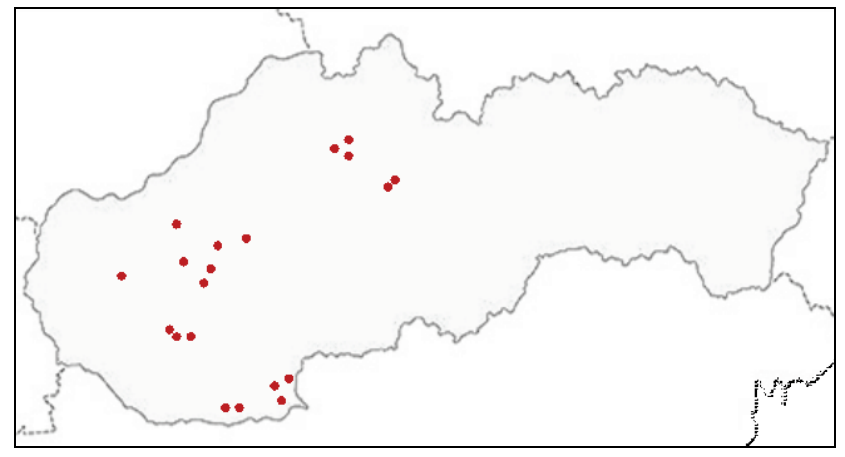

Fig. 1. Localization of Sambucus nigra L. genotypes within Slovakia using GPS system: the data used to produce this figure can be found in Table I

Morphometric analysis. The measurement of morphometric parameters was carried out on 70 pollen grains from each genotype using the AxioVision Rel. 4.8.2.0 program. The measurements were made in micrometers $(\mu \mathrm{m})$. The characterization of pollen grains was calculated by taking the following parameters: the polar axis $(\mathrm{P}-$ the line connecting the proximal and distal pole), the equatorial axis (E-the line perpendicular to the polar axis and located in the equatorial plane), proximal/equatorial ratio $(\mathrm{P} / \mathrm{E})$. The pollen grains were studied at the laboratory of the Department of Tropical and Subtropical plants of NBG using an electron microscope Carl Zeiss LS 15, and the microphotographs were taken. The description terminology has been established with regards to Erdtman (1952), Punt et al. (1974, 2007), Böhnke-Gütlein \& Weberling (1981), Halbritter (1998), Halbritter et al. (2018).

The comparative morphological study of the pollen grains was performed according to the working rules on the SEM JEOL JSM-6390 in the conditions of low vacuum $(\mathrm{P}=60 \mathrm{~Pa})$ with the following zooming: 500 times - during the measurements; $1,000-10,000$ times - while taking the pictures of the exine sculpture features. Using the regime of low vacuum allows the pollen to be studied without its preliminary chemical treatment and undistorted data to received about the research object, which makes the process of the probe preparation easier. Typical exine patterns, shape, size, and the dimensions of pollen grains for each S. nigra genotype were determined by using a scanning electron micrograph (SEM).

Statistical analyses. Basic statistical analyses - the minimal and maximal values of the traits, arithmetic means, and coefficient of variation $(\mathrm{CV}$, $\%$ ) were performed using PAST 2.17. Results of the morphometric analy- sis were determined by mean \pm standard deviation (SD) and statistical significance was estimated. The level of variability was determined by Stehlíková (1998). Pearson's correlation coefficient was used to depict the relationship between the two traits. Hierarchical cluster analyses of similarity between phenotypes were computed by the Bray-Curtis similarity index and were performed using PAST 2.17. Principal component analysis (PCA) was performed to evaluate relationships among variables and some possible genotype groupings based on similar properties by using XLSTAT procedure (XLSTAT 7.5, Addinsoft, USA). All the observed traits were shown in graphic form.

Table 1

Localities of Sambucus nigra L. genotypes in Slovakia and their altitude

\begin{tabular}{|c|c|c|c|}
\hline Genotype & Locality & Region of Slovakia & Altitude, ma.s.l. \\
\hline $\mathrm{SN}-01$ & Mošovce & Central Slovakia & 484 \\
\hline $\mathrm{SN}-02$ & Blatnica & Central Slovakia & 495 \\
\hline $\mathrm{SN}-03$ & Topol'níky & South-Westem Slovakia & 111 \\
\hline SN-04 & Blatnica & Central Slovakia & 495 \\
\hline $\mathrm{SN}-05$ & Budmerice-Ružindol & Western Slovakia & 176 \\
\hline $\mathrm{SN}-06$ & Trnava & Western Slovakia & 144 \\
\hline SN-07 & Cabaj-Čápor & Western Slovakia & 159 \\
\hline $\mathrm{SN}-08$ & Horná Štubňa & Central Slovakia & 624 \\
\hline SN-09 & Žihárec & South-Western Slovakia & 111 \\
\hline SN-10 & Bartošová Lehôtka & Central Slovakia & 390 \\
\hline SN-11 & Štúrovo & South-Westem Slovakia & 109 \\
\hline $\mathrm{SN}-12$ & Topol’níky & South-Western Slovakia & 111 \\
\hline SN-13 & Kamenica nad Hronom & South-Western Slovakia & 132 \\
\hline SN-14 & Vráble & Wester Slovakia & 144 \\
\hline SN-15 & Chl'aba & South-western Slovakia & 115 \\
\hline SN-16 & Topol'níky & South-western Slovakia & 111 \\
\hline SN-17 & Stúrovo & South-western Slovakia & 109 \\
\hline SN-18 & Pohronský Ruskov & South-western Slovakia & 131 \\
\hline SN-19 & Malé Zálužie & Western Slovakia & 160 \\
\hline SN-20 & Malé Zálužie & Western Slovakia & 160 \\
\hline
\end{tabular}

Note: altitude-meters above sea level.

\section{Results}

Pollen shape refers to the 3-dimensional form of a pollen grain concerning the $\mathrm{P} / \mathrm{E}$ ratio. Results of 20 tested genotypes of $S$. nigra pollen morphology were calculated for the polar (p.a.) and equatorial axis (e.a.), which showed that dry pollen grains are generally from small $(10-25 \mu \mathrm{m})$ to medium size type $(25-50 \mu \mathrm{m})$, in accordance with dimensions and $\mathrm{P} / \mathrm{E}$ ratio (Fig. 2) pollen grains are frame in prolate type. Their shape was characterized as tricolporate, oblate or spherical, sometimes oblate-spheroidal, in polar view pollen was 3-lobate and in equatorial view elliptical or circular.

An aperture is a region of the pollen wall that differs significantly from its surroundings in morphology and/or anatomy. The aperture is presumed to function as the site of germination and to play a role in harmomegathy - the mechanism permitting changes in the shape and size of the pollen grain due to varying hydration status. Colpi (elongated apertures) (p.a./e.a. ratio $>2$ ) were long, situated equatorially or globally distributed, on the edges more or lesser equal and clear edges with slightly pointed ends. Membranes of colpi were psilate with a smooth surface. Mainly pores were blurred, covered with margins of colpi. But in very rare cases pores were distinct.

In general depending on the pollination the outer pollen wall may be either highly ornamented, often with plenty of pollen coatings, mainly pollenkitt, or with a more or less of psilate pollen surface. The pollen wall of the tested samples was with tectum. Ectexine consisted of obvious, short, and thin rod-shaped reinforcing elements. They were sparsely located. The exine surface had verrucate and baculate sculpting with rounded cells. Sculpture of exine was reticulate or microreticulate or all over pollen surface or sometimes with foveolate apocolpium. Luminae were irregularly shaped, rather small in polygonal (often 4- or 5-angular) or rounded, rather small in mesocolpium; luminae decreasing in size towards the colpi and the apocolpium. Cells were small or medium size, circular, angled, or circular-angled by the shape. Sometimes at the bottom of cell columns are observed. 

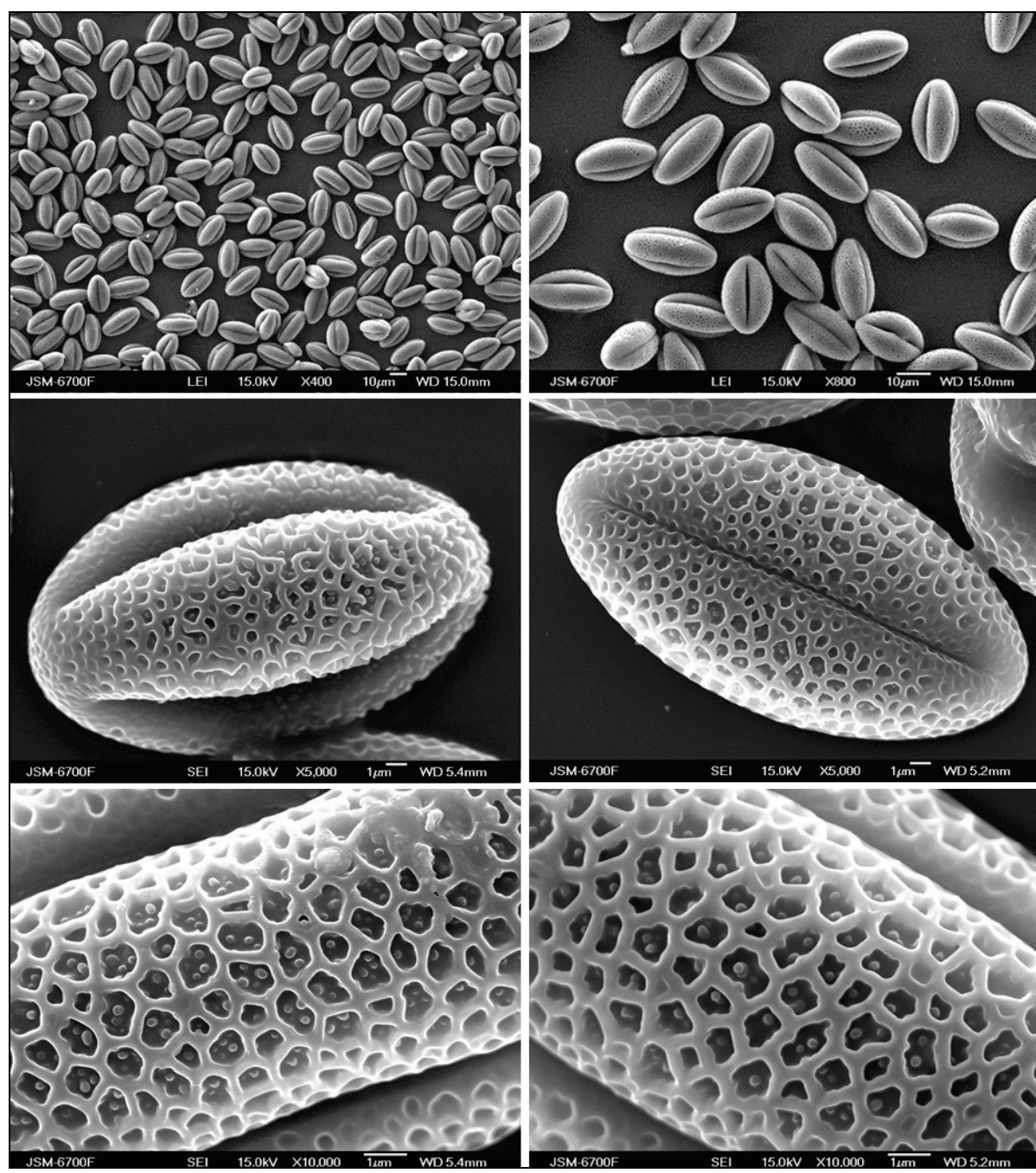

Fig. 2. Pollen grains of Sambucus nigra L. species in different positions A-B. Groups of pollen grains; Scale bar $=10 \mu \mathrm{m} \times 400$ and $10 \mu \mathrm{m} \times 800$. C-D. Dry pollen grains in reticulate apocolpia; Scale bar $=1 \mu \mathrm{m} \times 5000$. E-F. Detail of exine surface microreticulate ornamentation of mesocolpium, within lumina free columellae visible; Scale bar $=1 \mu \mathrm{m} \times 10000$

Pollen measurements for each genotype are listed in Table 2. The total length of the polar axis $(\mathrm{P})$ varied in the range of 18.23-29.91 $\mu \mathrm{m}$, the total width of the equatorial axis $(\mathrm{E})$ was in the interval $10.86-16.83 \mu \mathrm{m}$ (Table 2). The values of the variation coefficient show the values 2.62 $8.62 \%$ for polar axes and $4.40-7.17 \%$ for equatorial axes. Results of the morphometric analysis were also determined by mean \pm standard deviation (SD) and statistical significance was estimated. Figure 3 shows mean values of polar diameters in the range from $22.30 \pm 1.92 \mu \mathrm{m}(\mathrm{SN}-05)$ to $26.64 \pm 0.70 \mu \mathrm{m}(\mathrm{SN}-01)$ and equatorial diameters from $12.81 \pm 0.74 \mu \mathrm{m}$ (SN-06, SN-17) to $14.45 \pm 0.81 \mu \mathrm{m}(\mathrm{SN}-08)$, respectively. Means in each column are not significantly different $(\mathrm{P}<0.05)$. The shape index $(\mathrm{P} / \mathrm{E}$ ratio) depends on the elongation or roundness of pollen grains. Our samples' mean P/E ratio varied from $1.66 \pm 0.18$ (SN-05) to $2.02 \pm 0.11$ (SN10) (Fig. 4). Measurements showed that average values for polar axes are larger than $25 \mu \mathrm{m}$ (small-medium sized) for 6 genotypes ( $\mathrm{SN}-01, \mathrm{SN}-08$, $\mathrm{SN}-10, \mathrm{SN}-11, \mathrm{SN}-14$, and $\mathrm{SN}-18$ ) in various localities.

S. nigra grains have prolate spheroidal, subprolate, or slightly oblate (oblate spheroidal) shape (Maciejewska, 1997). The sizes of pollen grains S. nigra are very similar, the same for P/E ratio from $1.65 \pm 0.18$ (SN-05) to $2.02 \pm 0.11$ (SN-10), whereas lengths of p.a. and e.a. are in major intervals. The data indicates that hierarchical cluster analysis (HCA) separates pollen selections into three closely related groups - main clusters. Cluster III contains most genotypes that have nearly identical parameters. Other authors have also used cluster analysis to evaluate the morphological data of pollen, including pollen characteristics facilitating a better understanding of taxonomic classification, the genus or subgenus relationships or phylogenetic lineages (Grygorieva et al., 2010; Oswald et al., 2011; Teleb \& Salah-El-Din, 2014; Baldemir et al., 2018; Soares et al., 2018).
Table 2

Variation limits of pollen morphological traits of selected genotypes of Sambucus nigra L.

\begin{tabular}{|c|c|c|c|c|c|c|c|c|c|}
\hline \multirow[t]{2}{*}{ Genotypes } & \multicolumn{3}{|c|}{$\begin{array}{l}\mathrm{P}-\text { Polar } \\
\text { axis, } \mu \mathrm{m}\end{array}$} & \multicolumn{3}{|c|}{$\begin{array}{c}\text { E-Equatorial } \\
\text { axis, } \mu \mathrm{m}\end{array}$} & \multicolumn{3}{|c|}{$\begin{array}{l}\text { SI-shape } \\
\text { index }(\mathrm{P} / \mathrm{E})\end{array}$} \\
\hline & $\min$ & $\max$ & $\mathrm{V}, \%$ & $\min$ & $\max$ & $\mathrm{CV}, \%$ & $\min$ & $\max$ & $\mathrm{V}, \%$ \\
\hline SN-01 & 25.61 & 28.68 & 2.60 & 12.61 & 15.64 & 4.61 & 2.03 & 1.84 & 1.77 \\
\hline $\mathrm{SN}-02$ & 22.07 & 27.52 & 4.08 & 12.31 & 15.88 & 4.96 & 1.79 & 1.73 & 1.22 \\
\hline $\mathrm{SN}-03$ & 20.76 & 25.17 & 4.74 & 11.92 & 15.92 & 6.25 & 1.74 & 1.58 & 1.32 \\
\hline $\mathrm{SN}-04$ & 22.56 & 26.70 & 3.35 & 11.84 & 15.01 & 5.07 & 1.91 & 1.78 & 1.51 \\
\hline SN-05 & 18.23 & 26.88 & 8.56 & 10.86 & 16.83 & 7.12 & 1.68 & 1.60 & 1.20 \\
\hline SN-06 & 18.75 & 25.95 & 5.80 & 11.06 & 15.71 & 6.54 & 1.70 & 1.65 & 1.13 \\
\hline SN-07 & 19.04 & 27.22 & 7.13 & 11.68 & 15.46 & 6.08 & 1.63 & 1.76 & 1.17 \\
\hline SN-08 & 23.19 & 29.91 & 4.28 & 12.80 & 16.62 & 5.56 & 1.81 & 1.80 & 1.30 \\
\hline SN-09 & 22.66 & 25.92 & 3.11 & 12.09 & 15.77 & 5.16 & 1.87 & 1.64 & 1.66 \\
\hline SN-10 & 23.42 & 28.32 & 2.96 & 11.81 & 15.72 & 4.70 & 1.98 & 1.80 & 1.59 \\
\hline SN-11 & 23.72 & 26.93 & 2.64 & 10.94 & 14.90 & 5,14 & 2.17 & 1.81 & 1.95 \\
\hline $\mathrm{SN}-12$ & 21.42 & 25.80 & 4.23 & 11.78 & 14.89 & 4.37 & 1.82 & 1.73 & 1.03 \\
\hline SN-13 & 22.68 & 26.64 & 3.60 & 11.40 & 14.77 & 4.72 & 1.99 & 1.80 & 1.31 \\
\hline SN-14 & 23.85 & 27.06 & 2.97 & 11.16 & 14.43 & 4.68 & 2.14 & 1.88 & 1.58 \\
\hline SN-15 & 21.72 & 26.48 & 3.91 & 11.81 & 15.61 & 5.65 & 1.84 & 1.70 & 1.45 \\
\hline SN-16 & 22.38 & 26.51 & 2.96 & 11.74 & 15.26 & 4.57 & 1.91 & 1.74 & 1.54 \\
\hline SN-17 & 21.43 & 26.20 & 3.68 & 11.15 & 15.18 & 5.73 & 1.92 & 1.73 & 1.56 \\
\hline SN-18 & 22.48 & 28.55 & 4.12 & 12.18 & 15.86 & 5.72 & 1.85 & 1.80 & 1.39 \\
\hline SN-19 & 20.99 & 26.80 & 4.66 & 12.28 & 15.91 & 5.61 & 1.71 & 1.68 & 1.20 \\
\hline SN-20 & 21.43 & 26.85 & 4.60 & 12.31 & 16.43 & 5.66 & 1.74 & 1.63 & 1.23 \\
\hline
\end{tabular}

Note: $\min$ - minimal value; $\max$ - maximal value; $\mathrm{V}$ - coefficient of variation (\%). 


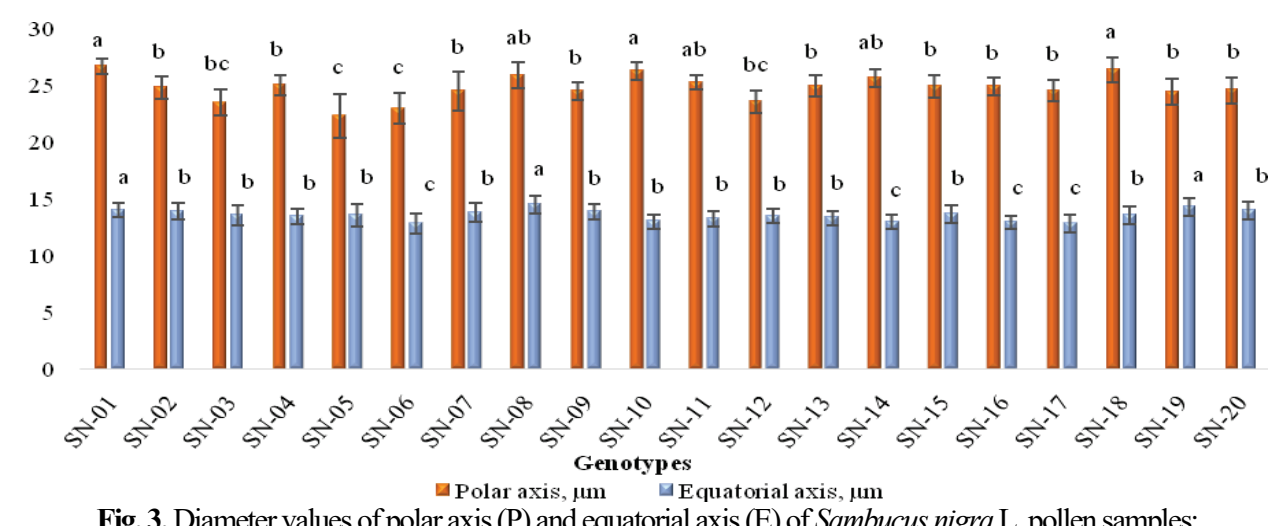

Fig. 3. Diameter values of polar axis $(\mathrm{P})$ and equatorial axis $(\mathrm{E})$ of Sambucus nigra $\mathrm{L}$. pollen samples: means in each column followed by different letters are not significantly different $(\mathrm{P}<0.05)$

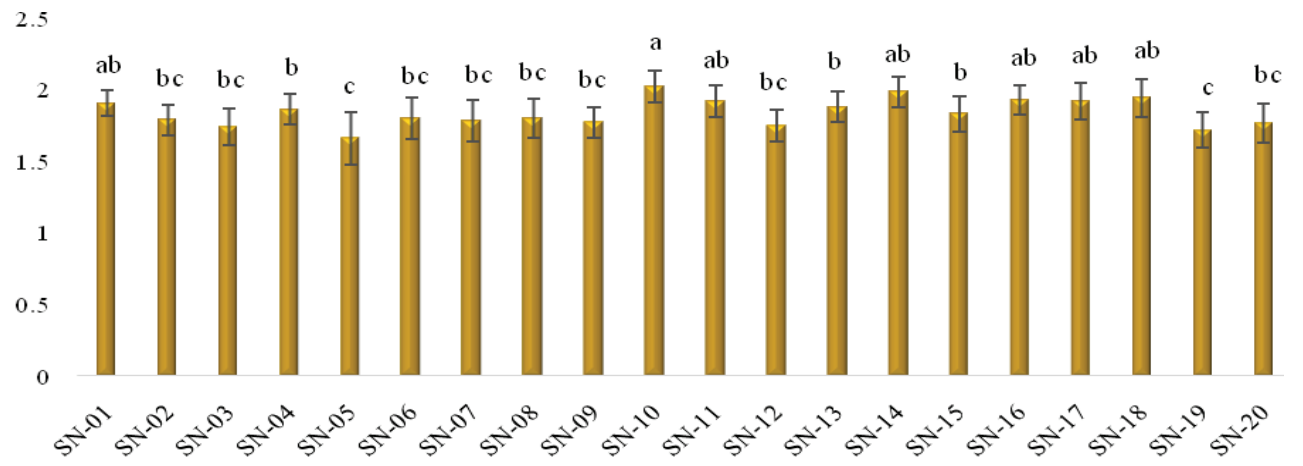

Fig. 4. Diameter values of shape index (P/E) of Sambucus nigra L. pollen samples: means in each column followed by different letters are not significantly different $(\mathrm{P}<0.05)$

The results of the cluster analysis simply illustrate the groupings of genotypes with similar morphological characters. Based on the cluster analysis we made a dendrogram of polar axes, equatorial axes, and shape index (Fig. 5).

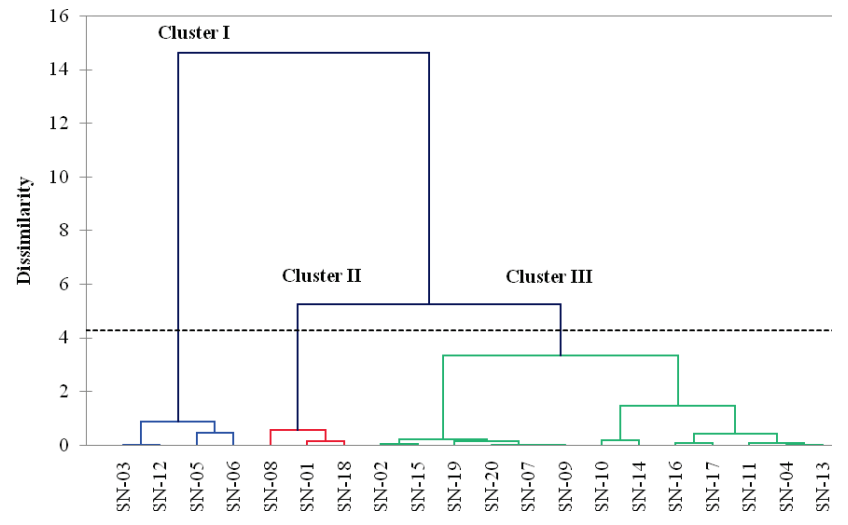

Fig. 5. Cluster dendrogram of morphometric parameters pollen of Sambucus nigra L. genotypes

More detailed relationships between genotypes were revealed by principal component analysis (PCA). The PCA used in our work showed that $100.0 \%$ of the variability observed was explained by the first two components (Table 3). PC1, PC2, and PC3 accounted for $61.7 \%, 3.3 \%$ and $0.01 \%$ respectively. $\mathrm{PC} 1$ was positively correlated with the polar axis and shape index. PC2 was positively correlated with the polar and equatorial axis, whereas the shape index showed a very low negative correlation. Positive values for $\mathrm{PCl}$ correspond to the genotypes with a higher polar axis as shown in Figure 5. Genotypes SN-01, SN-10, and SN-18 were included in this group. The highest negative values for $\mathrm{PC} 1$ indicate the genotypes with the smallest polar axis. This group includes genotypes $\mathrm{SN}-05$ and $\mathrm{SN}-06$ (Fig. 6). The genotypes $\mathrm{SN}-08$ and $\mathrm{SN}-19$ which the highest PC2 due to the highest equatorial axis. The positive PC3 value indicates the largest shape index. These characteristics were observed in genotype $\mathrm{SN}-10$.
Table 3

Eigenvalues and proportion of total variability, eigenvectors of the three principal components (PC), and component scores for Sambucus nigra L. pollen 20 genotypes

\begin{tabular}{lccc}
\hline \multirow{2}{*}{\multicolumn{1}{c}{ Selection }} & \multicolumn{3}{c}{ Component scores } \\
\cline { 2 - 4 } & \multicolumn{1}{c}{ PC1 } & PC2 & PC3 \\
\hline Eigenvalue & 1.852 & 1.148 & 0.000 \\
Variance (\%) & 61.730 & 38.257 & 0.013 \\
Cumulative & 61.730 & 99.987 & 100.000 \\
\hline \multicolumn{1}{c}{ Variable } & \multicolumn{3}{c}{ Component loadings } \\
\cline { 2 - 4 } & $\mathrm{PC} 1, \lambda=61.73$ & $\mathrm{PC} 2, \lambda=38.25$ & $\mathrm{PC} 3, \lambda=0.01$ \\
\hline Polar axis, $\mu \mathrm{m}$ & 0.577 & 0.578 & -0.577 \\
Equatorial axis, $\mu \mathrm{m}$ & -0.360 & 0.814 & 0.456 \\
SI-shape index & 0.733 & -0.056 & 0.677 \\
\hline
\end{tabular}

\section{Discussion}

Punt et al. $(1974,1976)$ divided the family Caprifoliaceae into 10 distinct pollen types viz., and determined that Sambucus nigra-type pollen grains are (2-), 3-Zonocolporate, $\mathrm{P} / \mathrm{E}$ ratio is suberect to erect; ectoaperturecolpus, long and wide, deeply sunken; end acute to slightly obtuse; bridge either distinct or indistinct and narrow; membrane nudate; endoaperture lalongate colpus, rather indistinct without costae; ornamentation - reticulate; lumina irregularly shaped, rather small in mesocolpium; lumina decreasing in size towards the colpi and the apocolpium; muri simplicolumellate; columellae in surface view circular; equatorial view - circular to elliptic; Polar view - circular or triangular with convex sides and apertures situated in the obtuse angles.

Maciejewska (1997) described pollen type according to P/E ratio as prolate polar axis predominate (prolate spheroidal - 30.5\% of observed pollen grains, subprolate $-44.8 \%$, prolate $-9.6 \%$ ); slightly oblate ones constitute no more than $1 / 5$ of observed samples (oblate spheroidal $18.1 \%$ ). Hexagonal polar view, with convex sides, elliptic equatorial view, sometimes also circular. Reticulate all over pollen surface or sometimes with foveolate apocolpium, muri simplicolumellate with smooth ridges. 


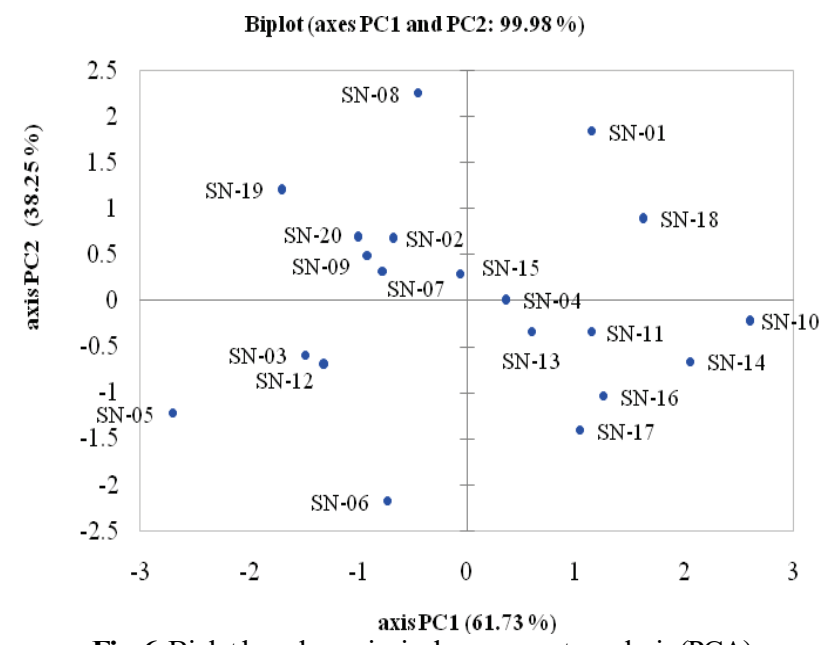

Fig. 6. Biplot based on principal components analysis (PCA) for pollen morphometric parameters of Sambucus nigra L. 20 genotypes

\section{Table 4}

Literature data on pollen morphometric parameters in the Sambucus nigra $\mathrm{L}$.

\begin{tabular}{|c|c|c|c|}
\hline Characteristic & Value & Autors & Country \\
\hline \multirow{9}{*}{$\begin{array}{l}\text { Polar } \\
\text { axis, } \mu \mathrm{m}\end{array}$} & $19.0-26.0$ & Punt et al., 1974 & Netherlands \\
\hline & $16.0-24.8$ & Maciejewska, 1997 & Poland \\
\hline & 25.0 & Muccifora et al., 2003 & Italy \\
\hline & 24.25 & Tămas et al., 2009 & Romania \\
\hline & $15.9-21.3$ & Tsymbalyuk and Bezusko, 2017 & Ukraine \\
\hline & $22.11-27.07$ & Horčinová Sedláčková et al., 2018 & Ukraine \\
\hline & $14.00-28.00$ & Wrońska-Pilarek et al., 2020 & Poland \\
\hline & $18.00-22.00$ & Wrońska-Pilarek et al., 2020 & $\begin{array}{l}\text { Germany, } \\
\text { Lithuania }\end{array}$ \\
\hline & $18.23-29.91$ & Our data & Slovakia \\
\hline \multirow{9}{*}{$\begin{array}{l}\text { Equatorial } \\
\text { axis, } \mu \mathrm{m}\end{array}$} & $15.0-22.0$ & Punt et al., 1974 & Netherlands \\
\hline & $16.0-22.0$ & Maciejewska, 1997 & Poland \\
\hline & 12.5 & Muccifora et al., 2003 & Italy \\
\hline & 12.85 & Tămas et al., 2009 & Romania \\
\hline & $13.3-18.6$ & Tsymbalyuk and Bezusko, 2017 & Ukraine \\
\hline & $11.98-17.29$ & Horčinová Sedláčková et al., 2018 & Ukraine \\
\hline & $12.00-24.00$ & Wrońska-Pilarek et al., 2020 & Poland \\
\hline & $16.00-22.00$ & Wrońska-Pilarek et al., 2020 & $\begin{array}{l}\text { Germany, } \\
\text { Lithuania }\end{array}$ \\
\hline & $10.86-16.83$ & Our data & Slovakia \\
\hline \multirow{7}{*}{$\begin{array}{l}\text { SI - shape } \\
\text { index }\end{array}$} & $1.02-1.50$ & Punt et al., 1974 & Netherlands \\
\hline & $0.89-1.42$ & Maciejewska, 1997 & Poland \\
\hline & $1.88-1.89$ & Tămas et al., 2009 & Romania \\
\hline & $1.70-1.76$ & Horčinová Sedláčková et al., 2018 & Ukraine \\
\hline & $0.82-1.57$ & Wrońska-Pilarek et al., 2020 & Poland \\
\hline & $0.90-1.25$ & Wrońska-Pilarek et al., 2020 & $\begin{array}{l}\text { Germany, } \\
\text { Lithuania }\end{array}$ \\
\hline & $1.08-2.36$ & Our data & Slovakia \\
\hline
\end{tabular}

Wrońska-Pilarek et al. (2020) presented pollen sculpture as reticulateheterobrochate, mostly microreticulate-heterobrochate pollen wall with lumina of different, often irregular shape; within the lumina, one to three free columellae, shorter than muri, often present. Outside the colpori, the exine ornamentation was microreticulate or microgranulate and in the middle of the colporus, it was usually psilate.

Almost in all literature data (Table 4), S. nigra pollen grains were described as small (10-25 $\mu \mathrm{m})$. Tămas et al. (2009), who examined in the Romanian flora and vegetation three species of Sambucus (S. nigra, S. racemosa, S. ebulus) by morphological traits by SEM analysis, determined that only $S$. ebulus had over $25 \mu \mathrm{m}$ as middle size type (25$50 \mu \mathrm{m}$ ), Maciejewska (1997) evaluated the Polish species of Sambucus (S. nigra, S. racemosa, S. ebulus) with low polar diameter for all samples. Wrońska-Pilarek et al. (2020) identified a total of 66 evaluated samples in Poland, Germany, and Lithuania, almost all the pollen grains were small, with just one medium-sized. S. nigra grains have prolate spheroidal, subprolate, or slightly oblate (oblate spheroidal) shape (e.g. Donoghue, 1985; Maciejewska, 1997; PalDat, 2020). The sizes of pollen grains S. nigra are very similar, whereas lengths of p.a. and e.a. are in major intervals, as well as measurements of Punt et al. (1974), Horčinová Sedláčková et al. (2018) or Wrońska-Pilarek et al. (2020). Simultaneously \& Maciejewska (1997), Tsymbalyuk \& Bezusko (2017), Wrońska-Pilarek et al. (2020) presented small differences between polar and equatorial intervals, which is related to the lesser values of SI-shape index (p.a./e.a. ratio). Studies of pollen samples from Slovakia and Ukraine (Horčinová Sedláčková et al., 2018) have presented wide ranges of pollen diameters, $\mathrm{P} / \mathrm{E}$ ratio (1.08-2.36) of Slovakian samples against the authors' study of Ukrainian samples (p.a.e.a. $=1.70-1.76$ ) and other data of Punt (1974), Maciejewska (1997), Muccifora et al. (2003), Tămas et al. (2009) or Wrońska-Pilarek et al. (2020) (Table 3).

Pollen size is an important diagnostic feature in the identification and characterization of hybrid offspring. Differences in pollen grain size may also occur between different genotypes of the same species (Miter et al., 2016). The size of the pollen grains can also vary within a single plant, the largest pollen grains are found in the best developed top inflorescences. The data of the authors on the size of the pollen grains of the same plant species are variable and may vary, often depending on the pollen treatment in the analyses. Various external factors (air temperature, precipitation) and plant nutrition can influence the size of pollen grains. Plants are known to produce fewer pollen grains but larger sizes to avoid desiccation stress during the flowering period (Ejsmond et al., 2011).

Palynological features are very valuable. Evaluated pollen characters may be a useful tool for systematics with significant diagnostic value. Pollen data combined with other morphological evidence (e.g., floral characters) have more recently become an important indicator of which genotypes may be the best representatives of species (Ulrich et al., 2012, 2013; Stuessy \& Funk, 2013).

\section{Conclusions}

The study of the S. nigra pollen via scanning electron microscope allowed us to determine the most important parameters which can be used to identify the representatives of species. The detailed pollen morphological and micro-sculptural characteristics were investigated, described, and analyzed by using a hierarchical cluster analysis dendrogram and BiPlot. The main parameters such as the form (the pollen grains' elongation, $\mathrm{P} / \mathrm{E}$ ratio) are specific for different Sambucus species. Results from our analyses showed small differences among $S$. nigra genotypes. Some of these pollen morphological parameters can be used for identification and comparison with the following analyses of Sambucus species.

The publication was prepared with the active participation of researchers involved in the international network AgroBioNet of the institutions and researchers for the realization of research, education, and development program "Agrobiodiversity for improving nutrition, health, and life quality". This work was supported by the Bilateral Scholarship of the Ministry of Education, Science, Research and Sport (Slovak Republic) and Visegrad Fund.

\section{References}

Accorsi, C. A., Bandini Mazzanti, M., Forlani, L., \& Speranza, M. (1987). Morfologia pollinica di Sambucus L. Italia Archivio Botanico e Biogeografico Italiano, 63, 153-194.

Almaraz-Abarca, N., Graça Campos, M., Ávila-Reyes, J. A., Naranjo-Jiménez, N., Corral, J. H., \& González- Valdez, L. S. (2007). Antioxidant activity of polyphenolic extract of monofloral honeybee-collected pollen from mesquite (Prosopis juliflora, Leguminosae). Journal of Food Compostion Analysis, 20, 119-124.

Aluri, R. J. S., \& Reddi, C. S. (1995). Explosive pollen release and pollination in flowering plants. Proceedings of the Indian National Science Academy, B61(4), 323-332.

Applequist, W. L. (2013). Report of the nomenclature committee for vascular plants: 65. Taxon, 62, 1315-1326.

Baldemir, A., Alan, S., Sahin, A. A., Paksoy, M. Y., \& Pinar, N. M. (2018). Pollen morphology of Scaligeria DC. (Apiaceae) in Turkey. Turkish Journal of Botany, 42, 462-477.

Barbosa, S. I. T. R., Silvestre, A. J. D., Simoes, M. M. Q., \& Estevinho, M. L. M. F. (2006). Composition and antibacterial activity of the lipophilic fraction of honeybee pollen from native species of Montesinho Natural Park. International Journal of Agricultural Research, 1,471-479. 
Basuny, A. M., Arafa, S. M., \& Soliman, H. M. (2013). Chemical analysis of olive and palm pollen: Antioxidant and antimicrobial activation properties. Herald Journal of Agriculture Food Science Research, 2(3), 91-97.

Böhnke-Gütlein, E., \& Weberling, F. (1981). Palynologische Untersuchungen an Caprifoliaceae. I. Sambuceae, Viburneae und Diervilleae. Tropische und Subtropische Pflanzenwelt, 34, 131-189.

Bremer, K., Backlund, A., Sennblad, B., Swenson, U., Andreasen, K., Hjertson, M. Lundberg, J., Backlund, M., \& Bremer, B. (2001). A phylogenetic analysis of $100+$ genera and $50+$ families of euasterids based on morphological and molecular data with notes on possible higher level morphological synapomorphies. Plant Systematics and Evolution, 229, 137-169.

Camerarius, R. J. (1694). Ueber das Geschlecht der Pflanzen (De sexu plantarum epistola). Uebersetzt und herausgegeben von M. Mobius. Ostwald's Klassiker der exakten Wissenschaften.

Candolle, A. P., \& Sprengel, K. (1821). Elements of the philosophy of plants. William Blackwood, Edinburgh.

Charzyńska, M., \& Lewandowska, E. (1990). Generative cell division and sperm cell association in the pollen grain of Sambucus nigra. Annals of Botany, 65, 685-689.

Donoghue, M. J. (1985). Pollen diversity and exine evolution in Viburnum and the Caprifoliacea sento lato. Journal of the Amold Arboretum, 66, 421-469.

Doyle, J. A. (2005). Early evolution of angiosperm pollen as inferred from molecular and morphological phylogenetic analyses. Grana, 44, 227-251.

Dresselhaus, T., Sprunck, S., \& Wessel, G. M. (2016). Fertilization mechanisms in flowering plants. Current Biology, 26, R125-R139.

Ejsmond, M. J., Wrońska-Pilarek, D., Ejsmond, A., Dragosz-Kluska, D., KarpińskaKolarczek, M., Kolarczek, P., \& Kozlowski, J. (2011). Does climate affect pollen morphology? Optimal size and shape of pollen grains under various desiccation intensity. Ecosphere, 2(10), 117.

Erdtman, G. (1945). Pollen morphology and plant taxonomy. III. Morina L. Svensk Botanisk Tidskrift, 39(2)

Erdtman, G. (1952). Pollen morphology and plant taxonomy. Angiosperms. An introduction to palynology I. Almquist and Wiksell, Stockholm.

Fægri, K., \& Iversen, J. (1989). Textbook of pollen analysis. 4th ed. John Wiley and Sons, Chirchester.

Farré-Armengol, G., Filella, I., Llusia, J., \& Peñuelas, J. (2015). Pollination mode determines floral scent. Biochemical Systematics and Ecology, 61, 44-53.

Friedman, J., \& Barrett, S. C. H. (2009). Wind of change: New insights on the ecology and evolution of pollination and mating in wind-pollinated plants. Annals of Botany, 103, 1515-1527.

Gee, C. T. (2001). The mangrove palm Nypa in the geologic past of the New World. Wetlands Ecology and Management, 9, 181-194.

Grew, N. (1682). The anatomy of plants, with an idea of a philosophical history of plants, and several other lectures. Read before the Royal Society. W. Rawlins, London.

Grygorieva, O., Brindza, J., Ostrolucká, M. G., Ostrovský, R., Klymenko, S., Nôžková, J., \& Tóth, D. (2010). Pollen characteristics in some persimmon species ( $D i$ ospyros spp.). Agriculture, 56(4), 121-130.

Halbritter, H. (1998). Preparing living pollen material for scanning electron microscopy using 2,2-dimethoxypropane (DMP) and critical-point drying. Biotechnic and Histochemistry, 73, 137-143.

Halbritter, H., Ulrich, S., Grimsson, F., Weber, M., Zetter, R., Hesse, M., Buchner R., Svojtka, M., \& Frosch-Radivo, A. (2018). Palynology: History and systematic aspects. Illustrated Pollen Terminology. Springer, Cham.

Heslop-Harrison, J. (1975). The Croonian lecture, 1974: The physiology of the pollen grain surface. Proceedings of the Royal Society of London. Series B, Biological Sciences, 190(1100), 275-299.

Horčinová Sedláčková, V., Grygorieva, O., Gurnenko, I., \& Brindza, J. (2018). Study of morphological characteristics of pollen grains of Sambucus nigra L. Agrobiodiversity for Improving Nutrition, Health and Life Quality, 2, 277-284.

Hu, C. C., \& He, C. X. (1988). Pollen morphology and Caprifoliaceae from China and its taxonomic significance. Acta Phytotaxonomica Sinica, 26(5), 343-352.

Kessler, R., \& Harley, M. M. (2004). Pollen. The hidden sexuality of flowers. Papadakis Publisher, London.

Kölreuter, J. G. (1761-1766). Vorläufige Nachricht von einigen das Geschlecht der Pflanzen betreffenden Versuchen und Beobachtungen 4. Leipzig, Gleditsch.

Kozáková, R., \& Pokomý, P. (2007). Dynamics of the biotopes at the edge of a medieval town: Pollen analysis of Vltava river sediments in Prague, Czech Republic. Preslia, 79, 259-281.

Kuprianova, L. A., \& Alyoshina, L. A. (1972a). Caprifoliaceae Juss. - zimolostnyje Pylca i spory rastienij flory evropejskoj chasti SSSR. Nauka, Leningrad.

Maciejewska, I. (1997). Pollen morphology of the polish species of the family Caprifoliaceae. Pt 1. Acta Societatis Botanicorum Poloniae, 66(2), 133-142.

Mitre, I. J., Mitre, V., Buta, E., Pop, R., \& Seatras, R. E. (2016). SEM observation, pollen viability and germination in some selected plum genotypes cultivated in Romania. Journal of the American Pomological Society, 70(3), 149-157.
Moore, P. D., Webb, J. A., \& Collinson, M. E. (1991). Pollen Analysis. 2nd ed. Blackwell Scientific Publications, Oxford.

Muccifora, S., Bellani, L. M., \& Gori, P. (2003). Ultrastructure, viability, and in vitro germination of the tricellular Sambucus nigra L. pollen. International Journal of Plant Sciences, 164(6), 855-860

Nikolaieva, N., Kačániová, M., Collado González, J., Grygorieva, O., \& Nôžková, J. (2019). Determination of microbiological contamination, antibacterial and antioxidant activities of natural plant hazelnut (Corylus avellana L.) pollen. Journal of Environmental Science and Health, Part B, 54(6), 525-532.

Nowicke, J. W., \& Skvarla, J. J. (1979). Pollen morphology: The potential influence in higher order systematics. Annals of Missouri Botanical Garden, 66, 633-700.

Oswald, W. W., Doughty, E. D., Ne'eman, G., Ne'eman, R., \& Ellison, A. M. (2011). Pollen morphology and its relationship to taxonomy of the genus Sarracenia (Sarraceniaceae). Rhodora, 113(955), 235-251.

Punt, W., Hoen, P. P., Blackmore, S., Nilsson, S., \& Le Thomas, A. (2007). Glossary of pollen and spore terminology. Review of Palaeobotany and Palynology, 143, $1-81$

Punt, W., Reitsma, T., \& Reuvers, A. A. M. L. (1974). The northwest European pollen flora. Caprifoliaceae. Review of Palaeobotany and Palynology. Elsevier Scientific Publishing Company, Amsterdam

Rao, A. N., \& Ong, E. T. (1972). Germination of compound pollen grains. Grana, $12,113-120$

Soares, R. L., Jesus, O. N., Souza, E. H., Rossi, M. L., \& Oliveira, E. J. (2018). Comparative pollen morphological analysis in the subgenera Passiflora and Decaloba. Annals of the Brazilian Academy of Sciences, 90(2), 2381-2396.

Stachurska, A., Sadowska, A., Bulaty, M., \& Kuszell, T. (1970). Lonicera periclymenum L., Wiciokrzew pomorski, Lonicera caprifolium L., Wiciokrzew przewiercień, Lonicera xylosteum L., Wiciokrzew suchodrzew, Lonicera tatarica L., Wiciokrzew tatarski, Lonicera nigra L., Wiciokrzew czarny, Sambucus nigra L., Dziki bez czarny (Caprifoliaceae). Kartoteka palynologiezna roślin polskich. Zeszyty przyrodnicze, Opolskie Towarzystwo Przyjaciół Nauk, 10, 150-155.

Stehlíková, B. (1998). Základy bioštatistiky. Slovenská Polnohospodárska Univerzita, Nitra.

Straka, H. (1952). Zur Feinmorphologie des Pollen von Salix and von Artemisia. Svensk Botanisk Tidskrift, 46(2), 204-227.

Stuessy, T. F. (1990). Plant taxonomy. Columbia University Press, New York.

Stuessy, T. F., \& Funk, V. A. (2013). New trends in plant systematics - introduction. Taxon, 62, 873-875.

Taia, W., Basahi, J., \& Hassan, I. (2013). Impact of ambient air on physiology, pollen tube growth, pollen germination and yield in pepper (Capsicum annuиm L.) Pakistan Journal of Botany, 45(3), 921-926.

Tămas, M., Pop, C., Martian, A., \& Barbu-Tudoran, L. (2009). Morphological research on indigenous Sambucus species pollen. Notulae Botanicae Horti Agrobotanici Cluj-Napoca, 37(1), 65-69.

Tank, D. C., \& Donoghue, M. J. (2010). Phylogeny and phylogenetic nomenclature of the Campanulidae an expanded sample of genes and taxa. Systematic Botany, 35(2), 425-441

Teleb, S. S., \& Salah-El-din, R. M. (2014). Pollen morphology of some species of genus Ficus L. (Moraceae) from Egypt. Egyptian Journal of Botany, 54(1), 87-102.

Tsymbalyuk, Z. M., \& Bezusko, L. G. (2017). Pollen morphology of representatives of the genus Sambucus (Sambucaceae/Adoxaceae) in the flora of Ukraine for spore-pollen analysis. Ukrainian Botany Journal, 74(2), 122-130.

Ulbricht, C., Basch, E., Cheung, L., Goldberg, H., Hammerness, P., Isaac, R., Singh Khalsa, K. P., Romm, A., Rychlik, I., Varghese, M., Weissner, W., Windsor, R. C., \& Wortley, J. (2014). An evidence-based systematic review of elderberry and elderflower (Sambucus nigra) by the natural standard research collaboration. Journal of Dietary Supplements, 11(1), 80-120.

Ulrich, S., Hesse, M., Bröderbauer, D., Bogner, J., Weber, M., \& Halbritter, H. (2013). Calla palustris (Araceae): New insights with special regard to its controversial systematic position and to closely related genera. Taxon, 62, 701-712.

Ulrich, S., Hesse, M., Bröderbauer, D., Wong, S. Y., \& Boyce, P. C. (2012). Schismatoglottis and Apoballis (Araceae: Schismatoglottideae): A new example for the significance of pollen morphology in Araceae systematics. Taxon, 61, 281-292.

Weberling, F. (1966). Caprifoliaceae. HEGI G. Ilustrierte Flora von Mitteleuropa $6(2), 3-87$

Wilcock, C., \& Neiland, R. (2002). Pollination failure in plants: Why it happens and when it matters. Trends in Plant Science, 7(6), 270-277.

Wrońska-Pilarek, D., Jagodziński, A. M., Bocianowski, J., Marecik, M., \& JanyszekSoltysiak, M. (2020). Pollen morphology and variability of Sambucus nigra L. - Adoxaceae. Biologia, 75, 481-493.

Ziarovská, J., Grygorieva, O., Brindza, J., \& Bežo, M. (2015). Identification of sweet chesnut pollen in bee pollen pellet using molecular analysis. Slovak Journal of Food Sciences Potravinarstvo, 9(1), 352-358. 